\title{
DANCE AS A MEDIUM FOR SOCIAL STABILITY: A CASE OF UMUADA BURIAL PERFORMANCE
}

\author{
Ofobuike Nwafor \\ Department of Theatre Arts \\ Nnamdi Azikiwe University \\ *http://dx.doi.org/10.4314/ujah.v14i3.8
}

\begin{abstract}
Societal moral decadence has given rise to a lot of vices in various communities, and this has lead to instability in the society. Social instability is the bases for underdevelopment and economic backwardness in the society. It hampers and hinders every effort and opportunity for human and material development. The deplorable situation has given rise to the cry for an effective medium to stabilize the society. Dance has been suggested as an effective tool to actualize this true African dream. As a live art, dance has the flexibility to incorporate the current trends in the society in its package. A dance project can present the happenings of a society to a community and can suggest how the community ought to be. Most importantly, dance is an art form that is so involving that dancers and audience could get so encompassed in participatory communalism that differences can be shade or forgotten in the course of performances. The Umuada burial performance is a typical example of a dance performance that can be so involving that in the process, it may become a medium for social stability.
\end{abstract}


Dance as a Medium for Social Stability: A Case of Umuada Burial Performance - Ofobuike nwafor

\section{Introduction}

The term "society" was derived from the Latin word societas, which in turn came from the noun socius, meaning comrade, friend, ally and can be used to describe a bond or interaction among parties that are friendly, or at least civil. Adam Smith was of the opinion that a society may subsist among different men from different background, as among different merchants, from a sense of its utility without any mutual love or affection, if only they don't endanger their environment, and they refrain from doing injury to one another (par 1). A human society is a group of people involved with each other through persistent relations, or a large social grouping sharing the same geographical or social territory, subject to the same political authority and dominant cultural expectations. Human societies are characterized by patterns of relationships (social relations) between individuals who share a distinctive culture and institutions; a given society may be described as the sum total of such relationships among its constituent members. In the social sciences, a larger society often evinces stratification and/or dominance patterns in subgroups. Used in the sense of an association, a society is a body of individuals outlined by the bounds of functional interdependence, possibly comprising characteristics such as national or cultural identity, social solidarity, language, or hierarchical organization.

The sense of community and humane living are highly cherished values of traditional African society. This statement remains true in spite of the apparent disarray in the experience of modern politics and brutal internecine wars in many parts of the Continent. In a typical African society, the community is 
basically sacred, rather than secular, and surrounded by several religious forms and symbols (Christopher I. Ejizu par1). To an African, everything in this world and beyond is explained in spiritual terms; consequently, nothing happens that is not interpreted as some form of divine intervention. B. Ray observed that,

to a great extent there is no formal distinction drawn between sacred and secular, religious and non-religious, spiritual or material. In many African languages there is no word for religion, because a person's life is a total embodiment of his or her philosophy (37).

Ray's observation is correct. In traditional African society the sacred and the secular are inseparable. There is no compartmentalization of life. All the various aspects of humans' life are interwoven. What religion forbids or condemns the society also forbids and condemns, and similarly society approves those things which religion approves or and sanctions. An offence against God is an offence against man, and in like manner an offence against man is an offence against God, since man is believed to be the God we see. Either offence is criminal. Forbidden criminal actions include adultery, breach of covenant, burglary, fornication, incest, kidnapping, irreverence and unkindness to parents, lying, murder, rape, seduction, speaking evil of rulers, swearing falsely, theft, sodomy and malice. All prohibited acts or taboos are crimes in African traditional religion and any person committing any of them is regarded as a criminal and is punishable. 
Dance as a Medium for Social Stability: A Case of Umuada Burial Performance - Ofobuike nwafor

Abnormal behaviour which is not in conformity with the norms of society are criminal acts (S.A. Adewale par1-2).

In traditional African society there exist no written legal documents showing what is legal or illegal, but traditional Africans have a code of conduct which they all know. This code constrains individuals to live in conformity with the well-being of society. The components of the code have been transmitted conventionally from generation to generation. It is a well established fact that Africans frowns at crime and criminality. Such vices are seen as taboo in land for most of them contributes largely to the underdevelopment of the society but economically, politically and spiritually. African societies have measures that are already in place to ensure that the member of the society particularly the younger generations are discouraged from engaging in nefarious activity that can destabilized the society and dance performance is one of the measures. Some dance performances serve as a medium for social stability in their societies. They check and balance the community.

African dance refers mainly to the dance patterns that are originally African, and are more appropriately African dances because of the many cultural differences in musical and movement styles. These dances must be viewed in close connection with African music traditions and cultivation of rhythm. African dance utilizes the concept of polyrhythm as well as total body articulation yet many African languages lack words to define music. Dances teach social patterns and values 
and help people work, mature, praise or criticize members of the community while celebrating festivals and funerals, competing, reciting history, proverbs and poetry; and to encounter gods. African dances are largely participatory, with spectators being part of the performance. With the exception of some spiritual, religious or initiation dances, there are traditionally no barriers between dancers and onlookers. Even ritual dances often have a time when spectators participate (Bakare Sebastian 81).

Dance and by extension sacred rituals, are integral part of daily African life. They are interwoven with every aspect of human endeavor, from the profound to the mundane. From birth to death, every transition in an individual's life is marked by some form of ritual observance. In a practical sense, these ubiquitous rituals are at the heart of religious practice in Africa. Many African dances are the means by which individuals relate to ancestors and other divinities. Whatever is the motivation of the dance, it combines the expression of human feeling with the higher aspirations of man to communicate with the cosmos. The supernatural entities which can benefit or hinder the endeavors of humankind are also composed of these same natural forces; to enlist their aid the human component is considered especially vital. In a sense, each divinity is created and empowered by the concentration and devotion of the worshipers, whose life force combines with that of, say an animal, or a river to bring the deity into power. If there is no human effort, there is no god and thus no chance to enhance the quality of life (High Tracey 11).

Dance is an integral part of a larger system. Dance expresses dynamic forces which constantly influence each other. Humans (both living and the dead), animals, vegetation and 
Dance as a Medium for Social Stability: A Case of Umuada Burial Performance - Ofobuike nwafor

minerals all posses this vital force in varying amounts. Dances mark key elements of communal life. For example, dances at agricultural festivals mark the passage of seasons, the successful completion of projects, and the hope for prosperity. In an annual festival of the Irigwe in Nigeria, men perform leaps symbolizing the growth of the crops. Dance does not merely form a part of community life; it represents and reinforces the community itself. Its structures reproduce the organization and the values of the community. For example, dances are often segregated by sex, reinforcing gender identities to children from a young age. Dance often expresses the categories that structure the community, including not only gender but also kinship, age, status, and, especially in modern cities, ethnicity. Traditional Dance has always played a very important role in the lives of Africans. Throughout history, Africans performed dances to celebrate a birth, harvest or death. Nicolas Akas explained that,

the various dance movements, represent some very important occasion in their lives as individual and society in general. This can be observed in ceremonies such as birth, circumcision, marriage and death, planting and harvesting, hunting, war and feast, the change of the moon, celebration of chieftaincy and so on. (50).

Communities relied on dance to ward off evil spirits, to ask the gods for prosperity, or to resolve conflict. Over the years dance has continued to serve these functions. For example, during farming and harvesting work the singing, dancing and clapping of hands entertains and motivates the hard-working farmers. 
African dance, according to R.F. Thomson, has four unique qualities. First, the body moves in a multi-unit fashion, where the head and arms may move to one rhythmic pattern while the feet follow a different time signature. Second, it is percussive in the sense that the dancer interprets the rhythmic nature of the music through movement. Third, though as a whole African dance is a community event, some dancers follow different parts of the rhythm, dancing "apart" from the crowd. Finally, African dance phrases, or sets of movements, overlap, creating a "call-and-response" pattern (664).

African Dance as we know it today is far cry from the shape it took and the purpose it served in its original tribal form, many moons ago. Friedler et al, recorded that, "African dance is a performing art deeply woven into the social fabric of Africa and generally involving aspects of music and theatre, as well as rhythmic bodily movement" (79). Within traditional African culture, the act of a dance is most often linked to the relationship or bond between spiritual forces and the community. Whether performed as a team dance, often in circular formations or as a solo dance, the performance would always nurture an inherent spiritual or expressive purpose and intention. African traditional dance has been linked to purposes on religious, social, educational and even therapeutic levels. Rituals for healing, funeral rites, remembering victories of past warriors, celebrating fruitful harvests or work, marriages, adolescence to adulthood, initiation rituals, defining authority and displaying sexual fertility are some of the many initiatives of dance rituals that have stemmed into African Dance (Gates and Appiah 558).

The history and traditions of African dance and movement centre on communication. According to Mamady Keïta, African dance is a way of life for the inhabitants of this 
Dance as a Medium for Social Stability: A Case of Umuada Burial Performance - Ofobuike nwafor

culture. Dance is used to symbolize the experiences of life; a way to heal sick individuals; a mode of prayer to the gods encouraging the growth of crops; and a way to tell the stories and pass on the traditions of the African culture. Dance can also serve as a medium of respect and homage, particularly the dead during funeral. Dance is an important part of Africa's history. Its significance encompassed all aspects of African life throughout time. Ceremonies that incorporate symbolic dance include transition from childhood to adulthood, changes in status within the community and social changes such as marriage (99). African entertainment performances, especially dances have their unique traditional roots, practices, norms, belief systems and developments. Thus, it reflects the ways of life of the people from one generation to the other.

\section{Dance Performance as Burial Rite of Passage.}

In Africa, ceremonies marking rite of passage abound. These ceremonies are mostly characterized by dance performances. These dance performances are not for entertainment sake only, they mark the transition from one level to another for the individual or group involved. Though African performances generally are highly artistic, its essence and purpose is beyond artistry. Apart from entertaining the people, some dance performance marks the severance from a particular race, and the birth of a new one, such as revealed by Wole Soyinka through the character Elesin Oba in the play Death and the Kings Horseman. When his courage was questioned Elesin boasted,

my reign is loosened, I am master of my fate. When the hour comes, watch me dance along 
the narrow path, glazed by the soles of my great precursors (153).

In the above statement, Elesin Oba is making reference to what can be tagged the "final dance". In this context, the "final dance" means a performance which one performs to perform no more, particularly at that level which he just performed. African dance often tells or reenacts stories. But this dose not in anyway imply that dance concept in Africa is dance-drama (though it is dramatic), but that African dances reflect the happenings in its society and are often inspired by events in the society. This is why dance is said to be the custodian of the people's history. Indigenous African dances reflect the societies of those that developed it. Primus captured this when he postulates that the history of dance is a narration of those changes in attitude and behavioural pattern of a people in a given time. These fluctuations are what gives rise to the concepts of art a given period its own distinctive qualities (6). Dance can also serve as a means of making prophetic statement. Prophetic dance occurs when dance performance is meant to motivate the people (performers and audience inclusive) by projecting the desire of their hearts through performance. Such dances are aimed at preparing the peoples mind and propelling them into believing that the future is better. An example is the Abriba war dance. This kind of dance encourages the warriors by reminding them about past victories and celebrating the victory of the battle that is yet to be fought in advance. To understand African burial performances, one has to understand the religious belief of the people. Ancestor worship is common in Africa and is an important part of religious practice. Ikenga reports that, 
Dance as a Medium for Social Stability: A Case of Umuada Burial Performance - Ofobuike nwafor

The dead are believed to live on in the world of the spirit (Spirit World). In this form they posses supernatural powers of various sort. They watch over their living descendants with kindly interest, but have the ability to cause trouble if they are neglected or dishonored. Proper attention to the ancestors, especially at funerals and memorial services result in helpful intervention on behalf of the living. It also ensures that a pious individual will be favourably received when he or she inevitably joins the spirit world (309).

This kind of beliefs explains why the elderly are treated with much respect in African Societies. Among people who indulges in ancestral worship, reverence to the elderly (particularly those that have attained hundred years and above) takes a mystical quality as though the living were slowly become gods. Each old man and woman is regarded as a priceless, irreplaceable treasure, the key to success in life and a citadel of knowledge. Because they have witnessed and participated in what has gone by, each one is appreciated as bearer of wisdom and experience in a society where custom and tradition are cherished. Guidance is often solicited from the elderly to solve questions of tradition or settle personal or family dispute. Death in Africa is determined by the age of the deceased. Death can be said to be tragic if the deceased is still in his prime. But in the case of an elderly person, such death is not tragic but a celebration of life. Africans believes that death is for the elderly and not for the young. It is not ideal for parents to bury the wards in an African view and philosophy of life. When the young dies in a typical African society, the 
burial is often low key. Such burials are not approached with the fanfares that are often characterized by the burial of an elderly person. The burial ceremony of an elderly person serves as a form of salutation to the deceased. It is a kind of the last homage and a celebration of life accomplishment or a life well spent. Though performances exist in virtually all the burials in Africa, but the intent and purpose may vary. In a tragic (young man's) burial, the performances are not merrymaking. Such burial is a time for sober reflection, and its performances are often dirge and slow body movement. In such burial it is quite easy to spot the women dance around the corps wearing long looks and the lyrics of their song says it all (Ikime 95).

In the play Nwokedi by Esiaba Irobi, the principal character Nwokedi ask his father (Nwokedi senior) if "the dirges we sing at funerals are for the living or the dead?" (?). Funeral dirge is a burial performance among several others, but its purpose, essence and function is what many like Nwokedi junior is yet to comprehend. Burial performances plays dual function; it serves the living and the dead as well. If not for the dead the living would not have gathered. On the other hand, there would not have been any burial for the dead if the living fails to gather together. What this implies is that burial performance such as dance are geared primarily towards appeasing the spirit of dead as the soul is encouraged to move on and join the ancestral world. Such performances also tends to encourage the living (the bereaved in particular), letting them not to loose hope or give up in life for tomorrow can be promising. It is pertinent that any dance performance marking a burials rite of passage is inline with the deceased beliefs when he was among the living. It is believed that the soul must pass through a familiar rout if it must not get lost in the journey to the 
Dance as a Medium for Social Stability: A Case of Umuada Burial Performance - Ofobuike nwafor

ancestral world. Burial performances serve as source channels through which the soul must travel to get to its destination. A familiar song, a familiar rhythm and a familiar dance can guild the dead through the abyss to the next world. One of such dance performance which is quiet popular and synonymous in Igbo culture is the Umuada burial performance.

\section{The Concept of Umuada}

In Nigeria, the Igbo speaking tribe are known to be one of the three major tribes in the country, others are Yoruba and Hausa. The Igbo's are rich in cultural heritage with artistic attributes. Most Igbo culture are said to be gender friendly. Cultures abound in some Igbo lands that are beneficial to the female gender. The Igbo marriage system is a typical example of their numerous cultural heritages that is gender friendly. In a typical Igbo cultural setting, a full moon prior to the marriage ceremony, the bride to be will be treated like a queen. She will be exempted from all kind can of labour. During this period she will be indoors, and will be served all kinds of rich delicacies. On the wedding day proper the husband and his family, and including the bride's family, together with friends and well wishers will shower the lady with rich and expensive gifts, such as cloths, cooking items and so no. Even in her husband's house she is entitled to some elevated positions by the virtue of being the lady of the house.

Matters pertaining to women are handled by women themselves in Igbo land. The women folk are usually governed by the eldest among them who is in a good health condition to discharge her duty. The women folks in every Igbo culture can be classify into two groups; the Umuada and Ndinwunye. The 
umuada are daughters of the land, while Ndi nwunye are those women married from other lands by the sons of the land In Igbo culture every girl born in the family is by the virtue of her birth nwada, and it is all the nwada that makes up the umuada. Umuada is the plural of nwada. In her own definition M O Ene explains that,

Umuada is a compound collective noun formed from "ụmụ" and "ada." Ada means "daughter"; umụ is a generic plural prefix that conveys the sense of many. Most naturally, every Igbo woman is "ada" (a daughter) of a certain community and is recognized as such for all the days of her life. Although it is used often in referring to the first daughter of a family ("adaobi"), ada generally means a female child (par2).

The Umuada or Umuokpu as it is called in some part of Anambra state is a collective of all daughters of a particular clan, village, or town, whether old, young, single, married, separated, or divorced. It is the inalienable right of every daughter of a particular place, without exception whatsoever, to belong to Otu Umuada, the society of native daughters. The Umuada has a strong position pertaining to the political system of the Igbo culture, particularly in matters concerning the women. The strength of umuada in a given culture depends on how much the culture of that particular community in question permits, or how strong the organization happens to be.

Basically the role of Umuada ranges from social, to political responsibility. Socially the umuada are factors to reckon with. They are the social pillars in their communities. No event or 
Dance as a Medium for Social Stability: A Case of Umuada Burial Performance - Ofobuike nwafor

ceremony can hold in the community without the umuada playing a significant role. Commenting on the social prowess of Umuada, Ene deposited that,

in all social functions, from marital rites to titletaking, Umuada play important roles.They are pampered and treated right, or they would raise hell... and no one wants to tango with them as a group. In many marital rites, the intending husbands give them special treats to win their approval because a no-vote could cause a rejection of the proposal by the Umunna. In many cases, Umuada act as middlepersons, steering assumed good guys from their husbands' community to potentially good girls in their native community (par11).

In most community some key and sensitive issues cannot be passed into law without the approval of Umuada, particularly if that issue affects the women. Cases abound of places were matters that were unable to be handled by the men folk including the Amala which is the highest governing body in most communities of Igbo cultural heritage were solved by the umuada. Ene threw more light when she reported that,

in certain cases when the approximate male counterpart called Umunna ("sons of the soil") fail to agree on an issue, Umuada will step in and resolve the matter. In complex conflicts of conjugal character, the intervention of Ụmuada is always a given. In such matters, the men (Umunna) take a backseat and abide by the 
rulings of Umuada. Umuada also plays important roles in many matters of birth, puberty, marriage, and death-the four major cycles of life (par5).

Communities treat the children of Umuada specially, even though they belong to different clans or towns. If the children of Umuada encounter difficulties, they and their families are welcome to come back to the community as umudiala (children of a citizen). They can stay for as long as they wish, but they are encouraged and supported to return to their father's community as soon as conditions permit. The role of Umuada in the preservation and promotion of peace and stability in the society needs not be overemphasized.

\section{Umuada Burial Performance.}

In and interview with one Nwada Ifenyinwa Nwafor, of Eziagu town in orumba south loacal government area of Anambra state, it was gathered that burial ceremony is one of the events in Africa in which the umuada functions significantly. According to Ifenyinwa, when someone dies the Umuada will contribute item such as food stuff, cash, and other materials to the bereaved family. But one significant function of the Umuada in a burial ceremony is the burial dance performance. The Umuada stay at the burial ceremony for about three nights consoling the bereaved through songs and dances. In their song the Umuada highlights those good qualities of the deceased while he or she was alive. Such good song goes along way to pacify the deceased family. It makes them to realize that their loss was not in vain. The performance is not only for the living; the dead are also beneficiaries for the spirit of the dead which is believed to be hovering around the house until the burial is done also get pacified. 
Dance as a Medium for Social Stability: A Case of Umuada Burial Performance - Ofobuike nwafor

During burials the Umuada are stationed at a particular post (often at the central living room) at the funeral venue. The umuada performances are mostly in morning and evening. In some communities the major performance of the Umuada is at night on the eve of the burial (wake keep). On this day the Umuada (home and abroad) will gather at the burial venue solely to perform. This particular performance is of high significant to the whole issue of the burial. In Utuh Nnewi based on the account of Nwada Tracie Ezeajughi, it is a taboo for one to sleep particularly a member of the deceased family during the Umuada performance. The umuada performs throughout the night to the early hours of the morning. Nwada Tracie went on to explain that the umuada songs are composed with the life experiences of the deceased. One of the Umuada popular songs will say,

ole ndi ejiri maka ha nyie akwa kara nka? Ole nid eji maka ha rie nri gbara ora? Ngwa puta nu nogbo bia gba egwu.

The song is a call to the children of the deceased, for whom she made so much sacrifice during her life time to come and dance. Nwada Tracie was quick to add that such demand from the Umuada cannot be turned down. Apart from pacifying the living and the dead like mentioned earlier, the Umuada performance serves as medium of justice. For instant, if the deceased person was maltreated during her life time, maybe by the family particularly the children, the Umuada will use the burial occasion as an opportunity to deal with the culprit. Nwada Felicia Ude of Amaopkala in an interview narrated a particular case of a woman who was not well cared for by her first son when she was alive. Story has it that the sons turned his attention way from the mother even when her health was deteriorating. Funny enough the Youngman was a wealthy 
Lagos based business man and one of the illustrious sons on the land. During the lady's burial, the Umuada while singing and dancing demanded that the Youngman should come and dance to the insulting and derogatory music they composed for him. His attempt to reject the call made the Umuada abandon the burial. All attempt to pacify the Umuada in monetary and material terms met a dead end. The Umuada returned on the agreement that the Youngman must dance to the music, and he did.

During burials, Umuada are well cared for. Notable among their welfare package is the traditional thick creamy big cup of tea and gigantic loafs of bread they are served in the morning. According to Nwada Ifenyinwa, the history of tea and bread for breakfast for Umuada can be traced back many years ago in Umunze, Orumba South Local Government Area of Anambra State. She said that a boy of about nine years old was renowned in the village for being disrespectful to the mother. Things got to a stage were the boy due to some personal reason will pour away the mother breakfast which is usually tea and bread. With the passage of time the boy outgrew such lousy behaviour, established in life, got married with children and life went on. But during the mothers burial many years after the Umuada performed a dance with a music composed with the Youngman's unruly behaviour as a child. After their performance the Umuada told the Youngman to serve them rich bread and tea breakfast as penalty for all the mother's cup of tea he poured away as a child. This incident is believed to mark the origin of Umuada bread and tea breakfast.

Traditionally there is no burial without the Umuada involvement, and this gives them upper hand in their dealings. It is believed that no one, however influential or highly placed in the society can successfully win a fight against the Umuada. Cases like this serve as a deterrent to those who are inclined to 
Dance as a Medium for Social Stability: A Case of Umuada Burial Performance - Ofobuike nwafor

nefarious activities in the community. The fear of Umuada can said to be the beginning of wisdom.

\section{Conclusion}

Besides the burial performance the Umuada have other strategies which they check the activities of members of the community. Testimony of how Umuada confronted a well known rapist and child molester in Ohukabia village Nawfija several years back is still fresh in the mind of the people. On this particular occasion the umuada strip themselves naked and marched down to the house of the rapist. On their way they destroy anything they can lay their hands on such plantain, banana, paw paw, goat and chicken. With blood shot eyes, anger and venom burning in them, they descended on the rapist on arriving in his house and beat him mercilessly. This particular incident marks the end of rape and child molestation in the community. During this kind of mission men dare not show their face outside. They all stay in doors until every thing is over.

The stability of the society depends largely on the culture the society practice. Without effective policing and some kind of measures that checks and balance the activity of the people, the society will become a jungle and a place were only the strong survive. The Umuada activities are still prevalent in our various communities at present, and they have continued to contribute significantly in shaping the society and making it a better place for one to live.

\section{Recommendation}

By the virtue of their birth the Umuada are stakeholders in their fatherland. Their activities become legacies and indelible 
foot prints in the sand of time which their loved one will inherit later in life. This can be said to be the secret and strength of their effective policing and sound judgment over the years. The federal of government Nigeria should borrow a leaf from the umuada Igbo. Those who are in position of judgment, policing and any kind of human development service should be made to function at their indigenous states, local government, towns and villages. Situations were police officers are posted far away from their places of origin creates rooms for activities that can destabilize the society.

\section{Works Cited}

Adewale, S. A. African Traditional Religion. wwwsul.stanford.edu. Accessed, $1^{\text {st }}$ May 2013.

Akas, Nikolas. "Dramatic Dance And Culture Preservation In A Multicultural Society:An Appraisal Of Ogho Umundugba Imo State Dance Festival". AMA: Journal of Theatre and Cultural Studies 6.1 (2011): 47-68.

Bakare, Sebastian. The Drumbeat of Life: Jubilee in an African Context. Geneva: WCC Publications, 1997.

B. Ray. African Religions, Symbol, Ritual and Community, New Jersey: Prentice-Hall, 1976.

Ejizu, Christopher. African Traditional Religion and the Promotion of Community-Living in Africa. www.afrikaworld.net/afrel/community.htm. Accessed $25^{\text {th }}$ April 2013. 
Dance as a Medium for Social Stability: A Case of Umuada Burial Performance - Ofobuike nwafor

Ene, M. O. The Concept of Umuada. www.kwenu.com. Accessed May 2013.

Esiaba Irobi. Nwokedi. Enugu: Abic Book, 1991.

Ezeajughi, Tracie. Personal Interview. Awka, 2013.

Friedler, et al. "Dancing Female: Lives and Issues of Women in Contemporary Dance". Choreography and Dance Studies 12 (1997): 136-241.

Gates and Appiah. Africana: The Encyclopedia of the African and African American Experience 1999 Basic Civics Books page 556

High, Tracey. African Dances of the Witwatersand Gold Mines. Cape Town: Cape Times Ltd, 1952.

Ikenga-Metuh, E. God And Man In African Religion. London: Geoffrey Chapman, 1981.

Mamady, Keita. A Life for the Djembe - Traditional Rhythms of the Malinke. Arun-Verlag. 1999

Nwafor, Ifenyinwa. Personal Iterview. Nawfija, 20013.

Obasi, Ikome. African Dance and Society. Ibadan: Heinemann Educational Books Plc, 2003.

Primus, Jacob. Teaching Children to Dance. Oxford: University Press, 2003. 
R.F. Thomson, The History of West African Dance - Kosmos Camp www.kosmoscamp.com/west-african-dance/

Smith,Adams.www.excellentfuture.ca/.../Adam\%20Smith' s\%20Concept\%20of\%20Soci... Acessed 28 April 2013.

Ude, Felicia. Personal Interview. Amaokpala, 2013.

Wole, Soyinka. Death and the Kings Horseman. Ibadan: Spectrum Books Limited, 1975. 